КОМПОНЕНТИ, КРИТЕРІЇ ТА РІВНІ ПРОФЕСІЙНОЇ ГОТОВНОСТІ

МАЙБУТНІХ ОФІЦЕРІВ ОРГАНУ ПРОБАЦІЇ ДО СОЦІАЛЬНО-ВИХОВНОЇ РОБОТИ 3 НЕПОВОЛІТНІМИ

\title{
COMPONENTS, CRITERIA AND LEVELS OF PROFESSIONAL READINESS OF FUTURE PROBATION OFFICERS FOR SOCIAL AND EDUCATIONAL WORK WITH JUVENILES
}

УДК $371.3+37.013 / 015.4: 376.58$ DOI https://doi.org/10.32843/2663$6085 / 2020 / 24-2.33$

\section{Шпортюк О.М.,}

старший викладач кафедри педагогіки та гуманітарних дисциплін Академії Державної пенітенціарної служби
У статті розкрито актуальність спеціальної фрахової підготовки майбутніх офріцерів органу пробації для роботи з неповнолітніми. Проаналізовані підходи науковців до визначення десрініцій «підготовка», «професійна підготовка», «готовність», Розглянуто поняття та визначено структуру готовності майбутніх офріцерів органу пробації до соціально-виховної роботи з неповнолітніми.

Визначено ц̆ теоретично обрурунтовано компоненти готовності майбутніх офріцерів органу пробації до соціально-виховної роботи з неповнолітніми, які мають відповідні кількісно-якісні прояви - показники, що висвітлюють і розкривають зміст готовHOCMi.

Для визначення готовності офріцерів органу пробації до соціально-виховної роботи з неповнолітніми виділено мотиваційно-ціннісний, когнітивно-змістовий; діяльнісний та особистісно-комунікативний компоненти. Конкретизовано критерії просресійної готовності до соціально-виховної роботи за кожним компонентом. Кожен критерій включає сукупність якісних показників, що розкривають зміст та надають характеристику готовності офріцерів органу пробації до соціально-виховної роботи з неповнолітніми. Ураховуючи визначені компоненти та рівні готовності, виокремлено високий, достатній, середній та низький рівень готовності до соціально-виховної роботи майбутніх осріцерів органу пробації. Рівень готовності до соціально-виховної роботи з неповнолітнім майбутніх офріцерів органу пробачіі залежить від організації цілеспрямованої підготовки до соціально-виховної роботи з неповнолітніми, яка передбачає формування мотиваційно-ціннісного інтересу до змісту майбутньої діяльності, засвоєння соціальнопедагогічних знань та умінь проведення соціально-виховних заходів, а також наявність особистісних цінностей та оволодіння комунікативним уміннями та навичками, що необхідні для есективного виконання професійної діяльності.

Ключові слова: професійна підготовка, готовність, соціально-виховна робота, неповнолітні, компоненти готовності; критерії, показники, рівні готовності.

The article reveals the relevance of special professional training of future probation officers for work with juveniles. For social and educational work with juveniles probation officers must have new work approaches, which necessitates a wider range of professional competencies, liquid knowledge, skills and abilities that will allow them to perform productively the key tasks of the probation service. Scientists approaches of definitions determination of "training", "professional training", "readiness" are analyzed. The concept and structure of future probation officers probation officers readiness for social and educational work with minors are considered. By the definition of professional readiness for social and educational work with juveniles we mean the acquisition of social and educational competence by the future officers of the probation body, which includes a set of pedagogical, psychological, legal knowledge, formation of professional psychological and pedagogical skills, abilities and values that stipulates effective problem solving of probation in accordance with the principles, enshrined in legislation on probation taking considering characteristics of juveniles.

The components of readiness of future probation officers for social and educational work with juveniles have been identified and theoretically substantiated, which have appropriate quantitative and qualitative manifestations - indicators that reveal the content of they readiness. To determine the probation officers' readiness for social and educational work with juveniles, motivational, cognitive and meaningful content; active and personal-communicative components were highlighted in the article.

The criteria of professional readiness for social and educational work for each component are specified. Each criterion includes a set of qualitative indicators that reveal the content and characterize the probation officers' readiness for social and educational work with juveniles.

Given the identified components and levels of readiness, such levels as high, sufficient, medium, and low levels of readiness for social and educational work of future probation officers are highlighted. The level of readiness for social and educational work with juveniles of future probation officers depends on the organization of purposeful preparation for social and educational work with juveniles, which involves the formation of motivational and value interest in the content of future activities, learning socio-pedagogical knowledge and skills of social and educational activities, as well as the presence of personal values and mastery of communication skills and abilities necessary for the effective performance of professional activities.

Key words: professional training, readiness, social and educational work, juveniles, components of readiness; criteria, indicators, levels of readiness.
Постановка проблеми у загальному вигляді. Важливим аспектом впровадження ювенальної юстиції в пенітенціарній системі стала необхідність підготовки кваліфрікованих кадрів для роботи з неповнолітніми в органах пробації, слідчих ізо- ляторах та виховних колоніях. За останні декілька років різко скоротилась кількість неповнолітніх засуджених до покарань у виді позбавлення волі та знизилась кількість утримуваних у виховних колоніях. Основне завдання з виховання, виправлення 
та ресоціалізації неповнолітніх порушників закону покладено на органи пробації. Офріцери органів пробації та секторів ювенальної пробації відповідно до Закону України «Про пробацію» та Типового Положення про сектор ювенальної пробації здійснюють нагляд та соціально-виховні заходи стосовно неповнолітніх засуджених до покарань у вигляді позбавлення права обіймати певні посади або займатися певною діяльністю, громадських робіт, виправних робіт; неповнолітніх осіб, звільнених від відбування покарання з випробуванням і повинні володіти необхідним об'ємом знань та професійних навиків для проведення соціальновиховної роботи заходів щодо неповнолітніх, реалізації пробаційних програм; забезпечення взаємодії з органами і службами у справах дітей, що здійснюють їх соціальний захист і профрілактику правопорушень, під час здійснення заходів пробації щодо неповнолітніх; узагальнення та аналізу інформації про неповнолітніх осіб для визначення їх потреб у наданні соціально-педагогічних, соціально-медичних, соціально-економічних, психологічних, юридичних та інорормаційних послуг.

Як бачимо, перед офріцерами органу пробації стоїть значно ширше коло завдань та посадових обов'язків ніж перед їх попередниками (інспекторами кримінально-виконавчої інспекції), що стосується проведення соціально-виховної роботи 3 неповнолітніми, володіння новими підходам у роботі й зумовлює наявність більш розширеного спектру профресійних компетентностей, ліквідних знань, вмінь та навичок, які дозволять продуктивно вирішувати ключові завдання служби пробації у тому числі із застосуванням соціальновиховних заходів. Тому виникає необхідність для розробки спеціального курсу та створення моделі підготовки курсантів до роботи 3 неповнолітніми в органах пробації.

Аналіз останніх досліджень і публікацій. Проблема підготовки та готовності до професійної діяльності була предметом досліджень багатьох учених у різних галузях: педагогіки, психології та права. Питанням створення та розвитку служби пробації, а також підготовці кваліфрікованого персоналу для даної служби свої наукові праці присвятили О. Беца, О. Богатирьова, А. Галай, О. Дука, Д. Ягунов, І. Яковець, О. Янчук. Педагогічні аспекти готовності до професійної діяльності такими вченими як І. Богданова, Л. Григоренко, І. Зязюн, Г. Нагорна, М. Малькова, В. Поліщук. Підготовку до соціально-виховної роботи з неповнолітніми, які перебувають у конфлікті з законом у своїх наукових працях, вивчали В. Анголенко, Л. Завацька, А. Капська, О. Караман, О. Третяк О. Федоренко, однак проблема визначення компонентів, критеріїв та рівнів готовності майбутніх офріцерів органу пробації до соціально-виховної роботи з неповнолітніми є не достатньо розкритою.
Виділення невирішених раніше частин загальної проблеми. Мета -проаналізувавши актуальні наукові праці, які висвітлюють тематику дослідження, вимоги щодо компетентності працівника пробації та нормативну базу, що стосується завдань та повноважень офріцерів органу пробації та секторів ювенальної пробації, визначити компоненти, критерії та рівні професійної готовності офріцерів пробації до соціально-виховної роботи з неповнолітніми, які перебувають у конфлікті з законом.

Виклад основного матеріалу. Для реалізації мети дослідження пропонуємо розглянути підходи науковців щодо формулювання поняття професійної підготовки та готовності; визначення компонентів, критеріїв (показників) та рівнів готовності майбутніх фрахівців до проведення соціально-виховної роботи з неповнолітніми.

Так, Словник української мови трактує «підготовку» як запас знань, навичок, досвід, набутий у процесі навчання, практичної діяльності [10, с. 418]. У наукових працях «підготовку» розглядають як процес навчання, набуття навиків реальних та потенційних працівників, необхідних для виконання відповідної роботи, сукупності робіт; як навчання, тобто спеціально організований процес формування готовності до виконання майбутніх посадових обов'язків.

Педагогічна енциклопедія розкриває зміст «профресійної підготовки» як сукупності спеціальних знань, умінь, навичок, якостей, трудового досвіду, і норм поведінки, що забезпечують можливість успішної роботи з певної професії; процес повідомлення учням відповідних знань і умінь [6, с. 573].

Так, професійна підготовка будь-якого фрахівця - це процес і результат фрормування їхньої готовності до роботи за фрахом, що здійснюється шляхом оволодіння сукупністю відповідних знань, вмінь та навичок. У Законі України «Про вищу освіту» зазначається, що професійна підготовка - це здобуття кваліфрікації за відповідним напрямом підготовки або спеціальністю [8].

Профресійна готовність до конкретного виду діяльності, як узагальнював дослідження вчених Ф. Думко, - це цілеспрямоване вираження особистості, що обіймає установку, погляди і переконання, систему відносин, мотивацію, емоційно-вольові та розумові якості, професійну компетентність та навички і вміння їі практичного втілення [2]. Поняття «готовність до роботи» на думку В. Поліщук, розглядається як прояв професійної компетентності майбутнього фрахівця, яка $€$ своєрідним синтезом професійних знань, індивідуального стилю професійної діяльності, творчого підходу до професійної діяльності, педагогічної реорлексії [7]. Л. Григоренко характеризує готовність як сукупність професійно-педагогічних знань, умінь, навичок та особистісних якостей, які забезпечують результативність роботи [1]. Готовність 
до соціально-виховної роботи 3 неповнолітніми М. Малькова визначає як засвоєння профресійних знань стосовно особливостей розвитку підлітків, специфіки соціально-педагогічної взаємодії $з$ дітьми підліткового віку, а також оволодіння толерантним стилем педагогічного спілкування 3 неповнолітніми [4].

Призначення готовності полягає в забезпеченні високих результатів під час виконання будь-якої роботи. Аналізуючи наукові джерела, можемо дійти висновку, що готовність передбачає:

1) наявність внутрішньої мотивації, позитивне ставлення до професійної діяльності, стійку зацікавленість цією діяльністю;

2) відповідні вимогам професійної діяльності риси характеру і здібності;

3) отримання необхідних знань, умінь та набуття певних професійних навичок.

Готовність фрахівця до виконання професійних обов'язків науковці досить часто розглядають у психологічному аспекті, який проявляється у суті властивостей та стані особистості. Із психологічного погляду готовність може визначатися як певна зібраність особистості, яка допомагає їй актуалізувати і використовувати свої можливості для успішних дій, тобто це є внутрішнє налаштування на певну поведінку в процесі виховної діяльності, що вимагає розуміння профресійних завдань, усвідомлення своєї відповідальності та бажання досягти успіхів [11, с. 160-171].

Отже, можна стверджувати, що у структурі педагогічного розуміння поняття «готовності» $€$ психологічний контекст, який включає в себе моральні і психологічні якості і можливості особистості.

Соціально-виховна робота $€$ одним із основних напрямів діяльності офріцера органу пробації. Під професійною готовністю до соціальновиховної роботи з неповнолітніми ми розуміємо набуття майбутніми офріцерами органу пробації соціально-виховної компетентності, що включає в себе сукупність педагогічних, психологічних, юридичних знань, сорормованість професійних психолого-педагогічних умінь, навичок та ціннісних орієнтирів, що зумовлюють ефективне вирішення завдань пробації відповідно до принципів, закріплених законодавством про пробацію та з урахуванням особливостей неповнолітніх; здійснення соціально-виховних, корекційних, профрілактичних заходів щодо неповнолітніх суб'єктів пробації.

Тому для визначення рівня підготовки майбутніх офріцерів органу пробації до соціально-виховної роботи з неповнолітніми, педагогічних умов та розробки моделі підготовки необхідно установити компоненти професійної готовності.

Під час дослідження компонентів готовності до соціально-виховної роботи 3 неповнолітніми майбутніх офріцерів органу пробації постає необхідність у визначенні базових понять, таких як «крите- рій», «показник». Можна стверджувати що критерії це ознака, на основі якої проводиться оцінювання; засіб перевірки, мірило оцінювання. У теорії пізнання - ознака істинності чи правильності [5].

Тобто критерії - це показники, за допомогою яких можна судити про розвиток та/або якогось явища або процесу. У науковій теорії під критерієм розуміють властивості, якості певного явища, що відображають його суттєві характеристики і підлягають оцінюванню. Критерії та показники повинні бути об'єктивними; включати найістотніші аспекти досліджуваного об'єкта чи явища; формулюватися конкретно, ясно й точно; вимірювати саме те, що хоче дослідник [3]. Критерій передбачає низку показників. Поняття «показник» означає характерну рису або відмінність досліджуваного об'єкта, своєрідний індикатор його якісні чи кількісних властивості, а також результати конкретного виду діяльності або процесу.

На підставі проаналізованої літератури та наукових підходів нами виокремлено компоненти готовності до соціально-виховної роботи 3 неповнолітніми майбутніх офріцерів органу пробації та їхні критерії (показники)

На наш погляд, готовність до соціально-виховної роботи 3 неповнолітніми майбутніх офріцерів органу пробації повинна складатись із таких компонентів:

1) мотиваційно-ціннісного;

2) когнітивно-змістового;

3) діяльнісного;

4) особистісно-комунікативного.

Мотиваційно-ціннісний компонент готовності майбутніх офріцерів органу пробації до соціально-виховної робот з неповнолітніми виражається у професійній зацікавленості майбутньою роботою в органах пробації, де знаходяться на обіку неповнолітні, які перебувають у конфлікті 3 законом. Даний компонент зумовлений структурою системи підготовки, яка повинна починатись 3 формування позитивної мотивації до навчання, усвідомлення необхідності такої підготовки. На необхідність формування мотивації професійної діяльності вказували такі відомі науковці, як М. Ануфррієв, О. Бандурка, В. Васильєв, Н. Гранат, І. Жданова, В. Кожевніков, Л. Корнєва, А. Маркова, В. Соболєв, О. Столяренко, О. Ярмиш та інші. Необхідність формування мотиваційного компоненту зумовлена логікою процесу підготовки, яка починається 3 фрормування позитивної мотивації до навчання, усвідомлення необхідності такої підготовки. Поняття мотивації є комплексним і включає в себе установки, мотиви, потреби, ціннісні орієнтації, ставлення й інтереси. Причому мотиваційний компонент професіоналізму поєднує в собі два види мотивації: пізнавальну та професійну. 3 одного боку, пізнавальна мотивація (пізнавальні потреби, інтереси, установки) необхідна для якіс- 
ного засвоєння знань, умінь та навичок, які треба засвоїти у процесі підготовки до профресійної діяльності. 3 іншого боку, враховуючи специсріку роботи офріцерів пробації й роботи 3 неповнолітніми зокрема, необхідно у процесі професійної підготовки формувати і професійну мотивацію, оскільки саме її сорормованість забезпечує якісне виконання професійних обов'язків, усвідомлення необхідності і важливості своєї профресії, установки на досягнення цілей та високих результатів у роботі, інтересу та позитивного ставлення до неї [9].

Сорормованість мотивації та усвідомлення суспільної значущості виконуваної роботи, а саме проведення соціально-виховної роботи з неповнолітніми забезпечує якісне виконання професійних обов'язків, установки на досягнення цілей, інтересу до взаємодії з неповнолітніми, позитивне ставлення як до неповнолітніх так і до самої роботи.

Мотиваційно-ціннісний компонент готовності майбутніх офріцерів органу пробації до соціально-виховної роботи 3 неповнолітніми характеризується розвитком профресійних інтересів, мотивів, установок, потреб, прагнень ефективно здійснювати діяльність, бажання виявити та реалізувати свої професійні здібності;

Якісні показники (критерії) готовності за цим компонентом визначаються:

- інтересом до обраної профресії, особистою зацікавленістю майбутнього офіцера органу пробації до проведення соціально-виховної роботи 3 неповнолітніми;

- стійкою мотивацією курсантів до організації професійної соціально-виховної роботи з неповнолітніми порушниками закону;

- ціннісними орієнтаціями (гуманність, толерантність, тактовність, справедливість, соціальна активність та небайдужість, відповідальність, добропорядність, прагнення до саморозвитку);

- позитивним ставленням до навчання, до проходження ознайомчої практики та стажування;

- стійкими мотивами до поглиблення й успішного вивчення фрахових дисциплін, потребою в досягненні позитивних результатів у навчанні та практичній діяльності, зацікавленістю у вирішенні соціальних та виховних питань неповнолітніх;

- інтересом до практичної роботи з неповнолітніми, які перебувають у консрлікті із законом, упровадженням диореренційованого виховного впливу;

- усвідомленням значущості та розуміння необхідності проведення соціально-виховної роботи 3 неповнолітніми, які знаходяться на обліку в органах пробації.

Когнітивно-змістовий компонент готовності майбутніх офріцерів органу пробації до соціально-виховної роботи 3 неповнолітніми характеризується змістом теоретичних знань про соціально-виховну роботу 3 неповнолітніми (понять, визначень, термінів, принципів, наукових теорій) та методичних знань (обізнаністю з фрормами, методами та програмами соціально-виховної роботи 3 неповнолітніми, які перебувають на обліку в органах пробації), засобів впливу на особистість, знання певних процедур, алгоритмів та взаємодій різних інституцій).

Якісними показниками (критеріями) готовності за цим компонентом вважаємо:

- якісне оволодіння майбутніми офріцерами органу пробації теоретичними знаннями із соціальної та пенітенціарної педагогіки, загальної та пенітенціарної психології, права, соціальної роботи, соціально-виховної роботи із засудженими;

- засвоєння засад кримінальної юстиції щодо неповнолітніх, міжнародних стандартів поводження 3 неповнолітніми порушниками закону, а також основ державної політики та соціальноправового захисту неповнолітніх, які перебувають у конорлікті із законом;

- засвоєння знань щодо основних соціальнопедагогічних понять і методичних інструментів роботи офріцера пробації з неповнолітніми та їхнім оточенням;

- оволодіння знаннями щодо теорії фрормування протиправної поведінки та фракторів, що зумовлюють її розвиток у підлітків;

- набуття курсантами знань щодо особливостей підліткового віку, специфріки потреб та інтересів неповнолітнього, кола проблем підліткового середовища, причин їх виникнення та механізмів нейтралізації;

- оволодіння основами кейс-менеджменту та умовами ефрективної профрілактичної/корекційної роботи 3 неповнолітніми;

- засвоєння змісту та різновидів пробаційних програм щодо неповнолітніх та алгоритму їх застосування.

Діяльнісний компонент готовності майбутніх офріцерів органу пробації до соціальновиховної роботи з неповнолітніми включає в себе професійні компетентності, що проявляються в уміннях і навичках організовувати та ефективно здійснювати практичну діяльність відповідно до завдань пробації та принципів, закріплених законодавством про пробацію та з урахуванням особливостей неповнолітніх суб'єктів пробації.

Якісними показниками (критеріями) діяльнісного компоненту готовності курсантів до професійної роботи у вказаному напрямку вважаємо:

- здатність використовувати теоретичний і методичний багаж знань у площині практичної професійної діяльності, самостійно здійснювати планування, організацію та аналіз соціальновиховної роботи;

- оволодіння методикою оцінки вірогідності вчинення повторного кримінального правопорушення неповнолітньою особою; 
- набуття вмінь щодо проведення оцінки ризиків та потреб у межах проведення соціальновиховної роботи із засудженими неповнолітніми в органах пробації;

- набуття вмінь проведення інтерв'ю $з$ метою збору інфрормації та проведення встановлення довіри з неповнолітнім;

- набуття навичок ведення випадку (кейсменеджмент);

- набуття навичок ефективної профрілактичної/ корекційної роботи з неповнолітніми;

- освоєння навичок реалізації пробаційних програм для неповнолітніх суб'єктів пробації;

- освоєння вмінь когнітивно-поведінкового втручання, мотиваційного консультування та набуття медіативних навичок;

- набуття вмінь взаємодії 3 державними та недержавним інституціями в тому числі волонтерськими організаціями.

Особистісно-комунікативний компонент готовності майбутніх офріцерів органу пробації до соціально-виховної роботи 3 неповнолітніми характеризується особистісно-ціннісними, професійними та комунікативними якостями та психологічними характеристиками майбутнього офріцера органу пробації, які сприятимуть його фаховим здібностям організовувати та проводити соціально-виховні заходи 3 неповнолітніми, а також есрективно спілкуватися, встановлювати з ними контакт та довірливі стосунки.

Якісними показниками (критеріями) готовності за цим компонентом вважаємо:

- особистісний - емпатія; спостережливість; толерантність; відповідальність; педагогічний такт; нервово-психічна стійкість; оптимізм; працездатність; уважність; ввічливість;

- комунікативний - вміння слухати; щирість; небайдужість; доброзичливість; відкритість; відсутність стигми; прийняття; уміння чітко та послідовно викладати інорормацію при спілкуванні; простота та зрозумілість фрраз при побудові речень, відсутність незрозумілих термінів; уміння фрормулювати закриті та відкриті запитання; уміння чітко відповідати на запитання неповнолітніх; уміння активно слухати, інтерпретувати, перефразовувати.

Ураховуючи зазначені компоненти та критерії готовності майбутніх офріцерів органу пробації до соціально-виховної роботи 3 неповнолітніми, на нашу думку, доцільно виділити три рівні сорормованості: низький, середній, достатній, високий:

Низький рівень готовності характеризується навчанням без особливої зацікавленості, відсутністю прагнення пізнавати нову інфрормацію, низькою активністю, відсутністю зацікавленості роботою за фрахом, байдужістю до проведення соціально-виховної роботи з підлітками, неусвідомленням значення необхідності профрілактики агресивної поведінки, мотивації позитивних змін особистості неповнолітнього та поліпшення соціальних стосунків; мають фрагментарні теоретичні знання, не вміють враховувати індивідуальні особливості підлітків та їхню специфіку у практичній соціально-виховній діяльності, не вміють аналізувати власні професійні дії та результати, не спроможні без допомоги викладача здійснювати планування та організацію індивідуальної соціально-виховної роботи $з$ неповнолітніми; відсутність прагнення в подальшому удосконалення та розвитку свої знань та умінь, не вміють аналізувати свої професійні дії та результати .

Середній рівень готовності характеризується такими рисами: переважають зовнішні мотиви до навчання, оволодіння фраховими знаннями та вміннями; нестійкою мотивацією до нових знань, періодичним прагненням до оволодіння уміннями та навичками; недостатньою мотивацією щодо проведення соціально-виховної роботи з неповнолітніми; виконує завдання, але без творчого підходу, безініціативність, недостатня активність, недостатня допитливість, недостатня уважність; неналежне оволодіння умінням спілкування $з$ неповнолітніми; недостатній рівень самостійності, слабо виражене бажання самостійно визначати напрямок подальших дій, неналежний рівень оцінки результативності своєї діяльності.

Достатній рівень готовності до соціальновиховної роботи з неповнолітніми характеризується: позитивним ставленням до освоєння теоретичних знань та практичних навиків; наявністю внутрішніх пізнавальних мотивів, які визначають їхнє прагнення оволодіти фраховими знаннями та уміннями; професійна спрямованість та здібності виявляються, як правило, під час вивчення професійно орієнтованих дисциплін; усвідомленням значення соціально-виховного впливу на неповнолітніх в органах пробації; достатнім оволодінням теоретичними знаннями та практичними уміннями щодо організації соціально-виховної роботи з неповнолітніми з ефективною реалізацією її ключових аспектів; умінням використовувати педагогічний інструментарій та комунікативні здібності; здатністю до здійснення адекватної оцінки своєї роботи.

Високий рівень готовності до соціальновиховної роботи з неповнолітніми в органах пробації характеризується: чітко вираженим інтересом до опанування знаннями, уміннями та навичками щодо проведення соціально-виховної роботи; освоєнням вітчизняного законодавства та міжнародних стандартів у сорері кримінальної юстиції щодо неповнолітніх; чітким усвідомленням необхідності проведення соціально-виховних заходів із неповнолітніми суб'єктами пробації; чітко визначеною професійною спрямованістю; у навчальній діяльності просліджується необхідність набуття досвіду, вмінь самостійно приймати рішення; наявністю системних знань про суть, зміст, фрорми та 
методи соціально-виховної роботи 3 неповнолітніми; мають місце стійкі прояви ініціативи, активності, критичного мислення; прояви допитливості та старанності; оволодіння методиками оцінки вчинення повторного кримінального правопорушення, застосування пробаційних програм, технологій кейс-менеджменту; знання вікових психологічних особливостей неповнолітніх; володіння комунікативними технологіями спілкування 3 неповнолітніми; наявність бажання працювати з підлітками,

Висновок. Визначені компоненти, показники та критерії готовності майбутніх офріцерів органу пробації до соціально-виховної роботи 3 неповнолітніми не вичерпують усебічність професійної підготовки курсантів до цього виду діяльності, однак дають змогу окреслити напрямки та змоделювати структуру підготовки у даному напрямку.

Таким чином, можна зробити висновок, що рівень готовності до соціально-виховної роботи 3 неповнолітнім майбутніх офріцерів органу пробації залежить від організації цілеспрямованої підготовки до соціально-виховної роботи 3 неповнолітніми, яка передбачає орормування мотиваційно-ціннісного інтересу до змісту майбутньої діяльності, засвоєння соціально-педагогічних знань та умінь проведення соціально-виховних заходів, а також наявність особистісних цінностей та оволодіння комунікативним уміннями та навичками, що необхідні для ефективного виконання професійної діяльності.

Перспективами подальших розробок вважаємо розроблення моделі підготовки до соціальновиховної роботи з неповнолітніми майбутніх офріцерів органу пробації.

\section{БІБЛІОГРАФІЧНИЙ СПИСОК:}

1. Григоренко Л.В. Формирование готовности студентов педвуза к профессиональной деятельности в процессе самостоятельной работы : дис. ... канд. пед. наук : 13.00.04. Кривой Рог, 1991. 162 с.
2. Думко Ф.К. Підготовка курсантів до професійнопедагогічної роботи 3 неблагополучними сім'ями : автореср. дис. ... канд.. пед. наук : 13.00.04 / Пвденноукраїнський держ. пед. ун-т ім. К.Д. Ушинського. Одеса, 2000. 29 с.

3. Дьяченко М.И., Кандыбович Л.А. Психологические проблемы готовности к деятельности. Минск : ГБУ, 1978. 182 с.

4. Малькова М. Формування майбутньої профресійної готовності майбутніх соціальних педагогів до взаємодії з девіантними підлітками : автореф. дис. ... канд. пед.. наук : 13.00.05. Луганський нац. пед.. ун-т ім. Т. Шевченка, Луганськ, 2006. 22 с.

5. Ожегов С.И. Словарь русского языка: Около 70000 слов / под ред. Н.Ю. Шведовой. Москва : Русский язык, 1991. 917 с.

6. Педагогическая энциклопедия / за ред. А.И. Каирова. Москва : Сов. энциклопедия. 1998. T. $3.880 \mathrm{c}$.

7. Поліщук В. А. Теорія і методика профресійної підготовки соціальних педагогів в умовах неперервної освіти : дис. ...д-ра. пед. наук : 13.00.04 / Тернопільський нац. пед. ун-т імені Володимира Гнатюка. Тернопіль, 2006. 454 с.

8. Про вищу освіту : Закон України від 01.07.2014 р. № 1556-VII. Відомості Верховної Ради України. 2014. № 37-38. Ст. 2004.

9. Просресійно-психологічна підготовка працівників слідчих підрозділів. Мотивація професійної діяльності працівника OBC URL : http://megalib.com. ua/content/9724_Motivaciya_profesiinoi_diyalnosti_ pracivnika_OVS.h̄tml.

10. Словник української мови: в 11 т. АН Української РСР, Ін-т мовознав. ім. О.О. Потебні / за ред: І.К. Білодід. Київ : Наук. думка, 1970-1980. Том 6. С. $832 \mathrm{c}$.

11. Федоренко О. Система підготовки майбутніх працівників міліції до соціальної та виховної роботи з підлітками. Професійно-педагогічна підготовка - вимоги сьогодення: збірник наукових праць. Луганська державна академія культури і мистецтв. Харківський обласний метод. каб. учб. закл. культури і мистецтв. Харків, 2007. 